Bond University

Research Repository

\title{
Benchmarking international construction costs
}

\author{
Langston, Craig Ashley
}

Published in:

Global Construction Data

DOI:

10.1201/9780429435911-3

Licence:

Other

Link to output in Bond University research repository.

Recommended citation(APA):

Langston, C. A. (2019). Benchmarking international construction costs. In S. Gruneberg (Ed.), Global Construction Data Routledge. https://doi.org/10.1201/9780429435911-3

\section{General rights}

Copyright and moral rights for the publications made accessible in the public portal are retained by the authors and/or other copyright owners and it is a condition of accessing publications that users recognise and abide by the legal requirements associated with these rights.

For more information, or if you believe that this document breaches copyright, please contact the Bond University research repository coordinator. 


\title{
Benchmarking International Construction Costs
}

\author{
Craig Langston \\ Centre for Comparative Construction Research, Bond University, Australia
}

\section{Introduction}

The title of this chapter reflects a preoccupation for practitioners, clients, economists, academics and government departments over many years, namely comparing the cost of construction in one country with the cost of construction in another. It is not just a simple matter of converting actual and/or estimated costs at a given date from one country to another through the use of currency exchange rates. Even within countries, different regions or cities will display variations in labour, material and plant costs, productivity ranges based on the availability of resources (including transportation distances) and contractor margins that take heed of market conditions. Furthermore, standards of construction, statutory requirements, local practices and concern for worker health and safety can impact on costs. Collectively, benchmarking international construction costs with a view to identifying value and performance is, and always has been, problematic (Best and Meikle, 2016).

The purpose of this chapter is to shed some light on the various conversion methods that are available for use and, objectively, make recommendations on which method(s) should be commonly adopted in practice. The routine approach for international benchmarking is to convert construction costs into US dollars (USD), so that at least all costs are in the same currency. Most practitioners appear to do this. Yet currency rates can be quite volatile, and therefore conclusions will depend to some extent on the timing of the study.

Purchasing power parity (PPP) is an alternative to currency conversion. The concept has been around since the $16^{\text {th }}$ Century, but was developed into its modern form by Gustav (1918), and used by economists ever since. It assumes that, in the absence of transaction costs and official trade barriers, identical goods will have the same price in different markets when the prices are expressed in a given currency (Krugman et al., 2010). Where this 
doesn't occur, the conclusion is that different countries have different domestic purchasing power.

The use of PPP as an alternative to traditional currency exchange rates is generally regarded as a superior approach (e.g. Rogoff, 1996; Langston and Best, 2005). PPP is an attempt to measure the economic wellbeing of people according to the country in which they reside. While not pretending to be an indicator of living standards, it does reflect the cost of living in-country and therefore forms a new baseline against which construction costs can be interpreted.

PPPs are defined as exchange rates that replace traditional currency exchange rates by taking into account the differences in prices between countries (Pakko and Pollard, 2003). They convert local costs into 'international dollars' compared to a nominated base country. The philosophy behind PPPs is the Law of One Price - namely that the cost of a good or service should be the same in different countries - else people would buy goods cheaper from one country and sell them at a profit in another (Baffes, 1991). However, whether the Law of One Price holds for any particular item depends on the item meeting four basic criteria (UBS, 2003). They are:

1. The item must be tradable

2. There are no impediments to trade

3. There are no transaction costs (such as transport) involved in trade of the item

4. The item is perfectly homogeneous across all locations.

If all four criteria are met then the price of the item should be the same in different places at the same time. In that case the cost of an item in currency $X$ should represent the same value as the cost of the same item in currency Y (Best, 2008).

The United Nations sponsored International Comparison Program (ICP) commenced in 1967 and now produces PPPs published by The World Bank Group for most countries on an approximate three-year cycle. These indices have been interpreted and extended to form the Penn World Table (PWT) produced by the University of Pennsylvania. The Eurostat- 
OECD joint program currently collects more detailed PPP data than the ICP, but for a much smaller set of countries. Indices for both ICP and Eurostat-OECD PPPs are expressed as a proportion of per capita gross domestic product. The Union Bank of Switzerland (UBS) has also been producing PPP data since 1970, again approximately on a three-year cycle. They use a basket of goods and services and express their data in three forms (using a base for Switzerland, United States or the Euro-zone respectively). One criticism of these programs is the time delay between data collection and publication. Another criticism is the cost of the process (Langston and Best, 2005). These PPPs relate to a country and tend to ignore the differences that exist between regions or cities within national borders.

Over the last decade or so, attention has turned to the development of indices that are industry-focused, and more recently data has been compiled related to particular cities. Turner and Townsend, a large multi-national firm of quantity surveyors and project consultants, published surveys of international construction costs since 2009 comprising local prices and conversion to USD. In 2013, for the first time, they additionally presented cost data in the form of PPPs based on a new 'exchange rate' called citiBLOC, which was developed as part of a major study of 337 high-rise projects of 20 storeys or more (completed between 2003 and 2012) throughout the five largest cities in Australia and the United States, representing two-thirds of the known population of such buildings in these locations (Langston, 2014). By pricing a representative basket of construction-related items covering labour, material and plant, a standard basket price in each city (in local currency terms) can be determined. The cost of this basket equals one citiBLOC. Thereafter, the cost of a project can be divided by the cost of the basket to obtain the equivalent number of baskets required to pay for the construction. Although the unit of measure is 'baskets', not currency, the answer is a comparative index that has no geographical boundaries. For example, if Project A in Los Angeles was 5 baskets $/ \mathrm{m}^{2}$ and Project B in New Delhi was 4 baskets $/ \mathrm{m}^{2}$, then the construction cost in Los Angeles would be $25 \%$ more than New Delhi.

The citiBLOC approach grew alongside Turner and Townsend's surveys to effectively become an international locality index at the granularity of cities. Table 1 illustrates the approach for Sydney, Australia.

Insert Table 1 here ...

This is an Accepted Manuscript of a book chapter published By Routledge in Global Construction Data on 12 August 2019, available online: https://doi.org/10.1201/9780429435911 
Perhaps the best way to describe PPP-adjusted values is to say that they express local prices in terms of purchasing power by weighting them according to a standard basket of relevant construction items (comprising common material, labour and plant items) that are made or otherwise available in-country. Imported goods and services should be avoided. The higher the PPP-adjusted value, the higher are the relative costs of building in one location over another.

Langston and Best (2005) first used the coefficient of variation (CoV) as a test for the Law of One Price. The thinking was that the method with the lowest CoV best reflected purchasing parity. They compared general PPPs produced by UBS and the World Bank, as well as USD currency conversion and the Big Mac Index. They found the latter was as good as any other method in some cities, but not in others. Hong Kong was a case in point, where the price of the Big Mac was about half of its expected value. This highlighted that the hamburger is not really a standard commodity across the world, but if one could be found there would be some confidence that its use in international cost comparisons would be superior to more costly and time-consuming methods. Large discrepancies were also found between the more established indices, particularly over the accuracy of the ICP data for Bangkok. Exchange rates were generally more volatile and displayed the greatest dispersion, suggesting that PPPs were more appropriate for use in practice.

Langston (2016) extended the notion of CoV testing by applying it to the data publicly available in Turner and Townsend (2013). Five different exchange rates were investigated, based on labour and material prices, composite prices, citiBLOC indices, the Big Mac Index and USD currency conversion respectively. He found that across the 23 surveyed cities, citiBLOC had the lowest CoV and hence better modelled the Law of One Price (i.e. where CoV theoretically equals zero).

\section{Method}

Turner and Townsend (2018) is the latest survey of construction prices, and embraces 46 cities. Over the last five years, they have used an identical framework for presenting their data. This makes it possible to objectively compare 2013 and 2018 costs and to see if the same conclusions reported in Langston (2016) can be replicated. The updated investigation 
doubles the number of cities, as can be observed in Table 2. Cities are ranked herein according to their cost of living using information compiled independently via the Expatistan website (https://www.expatistan.com/cost-of-living). The higher the index the more expensive is the cost of living in a particular city compared to a nominated base (set in this study as Sydney, Australia).

\section{Insert Table 2 here ...}

The first phase of the investigation compares USD and citiBLOC PPP exchange rates. As was done previously, three types of construction cost data are again used. Mean cost $/ \mathrm{m}^{2}$ for various building types (comprising residential, commercial, industrial, retail, hotels, hospitals, schools, carparks and airports) are compared. Then, unit rates for labour, material and plant are compared. Finally, unit rates for composite work items comprising a mix of supply and install activities are compared.

CoV is calculated as standard deviation divided by mean, and expressed as a percentage. Values below $20 \%$ typically demonstrate very low variance, values between 20 and $50 \%$ are considered good given the nature of the base data, while values over $50 \%$ suggest the prices are either erroneous or heterogeneous.

The second phase of the study compares five different exchange rates. As was done previously, a basket of labour and material unit rates $(L+M)$, a basket of composite work items (Composite), a basket of equally weighted labour, material and plant costs (citiBLOC), a McDonalds hamburger index (Big Mac) and USD exchange rates (Currency) are explored in turn.

\section{Results}

In the first instance, average construction prices for various building types in each city, expressed in both USD and PPP terms per square metre of gross floor area, are used to determine CoV. Table 3 shows these building types and computes the CoV across two datasets matching cities common with Turner and Townsend (2013) and extended in Turner and Townsend (2018). Langston (2016) previously found that of the 27 building types listed, 25 of them (i.e. 93\%) had a CoV that is lower for citiBLOC PPP than USD conversion. This is 
observed to increase to $100 \%$ (for both $n=23$ and $n=46$ ) using 2018 data. Again, all but one of these values has a CoV between 20 and $50 \%$.

\section{Insert Table 3 here ...}

A range of labour, material and plant items in each city is similarly used to determine CoV. The results are provided in Table 4. Langston (2016) previously found that of the 17 items listed, 12 of them (i.e. 71\%) had a CoV that is lower for citiBLOC PPP than USD conversion. This is observed to be $100 \%$ for labour and plant, and $63.64 \%(n=23)$ and $36.36 \%(n=46)$ for material using 2018 data. However, over half of the items had a CoV between $50 \%$ and $100 \%$, indicating higher volatility at this level of work breakdown. The reason material prices favour USD over PPP conversion is suspected to be due to the larger proportion of cities from developing countries in the extended database $(n=46)$ that have a higher reliance on imported construction products with embodied foreign labour in their manufacture.

\section{Insert Table 4 here ...}

Finally, a range of composite items (i.e. involving supply and install activities) in each city is similarly used to determine the CoV. These outcomes are contained in Table 5. Langston (2016) previously found that of the 19 items listed, 14 of them (i.e. 74\%) have a CoV that is lower for citiBLOC PPP than USD conversion. This is observed to be $73.68 \%(n=23)$ and 84.21\% ( $n=46$ ) using 2018 data. The majority of items had CoVs between 20\% and $50 \%$.

\section{Insert Table 5 here ...}

Overall, PPP-adjusted prices have lower CoVs than USD-adjusted prices, and therefore adhere more closely to the Law of One Price. Currency conversion, on the other hand, generally has higher CoVs, and although the approach is still valid when pricing construction works located in another country, it is not appropriate when benchmarking international project cost performance.

PPP is shown to be preferable compared to currency conversion. But citiBLOC PPP is not the only choice available. Three further PPP methods are added, so a total of five cost conversions strategies can be compared against each other. Once again, the method with the lowest CoV represents the best available option. 
The L+M PPP is calculated based on local prices for the 5 labour items and the 11 material items provided earlier in Table 4. Labour and material are combined using the proportion of labour and material costs in each citiBLOC (plant cost is distributed evenly between them). Similarly, a composite PPP is calculated based on local prices for the 19 items provided earlier in Table 5. Finally, prices for a McDonalds Big Mac hamburger (considered a default global commodity) are used to provide a non-construction alternative, sourced largely from https://www.economist.com/content/big-mac-index.

An equivalent cost $/ \mathrm{m}^{2}$ for buildings in each city is computed by taking the mean local price for each of the categories listed in Table 3 (i.e. residential, commercial, industrial, retail, hotels, hospitals, schools, carparks and airports). While it is obvious that this resultant cost $/ \mathrm{m}^{2}$ does not apply to any particular building type, the average of all types is done so as to add more stability to the accuracy of in-country prices. This cost $/ \mathrm{m}^{2}$ is then divided by the relative PPP (i.e. L+M, Composite, citiBLOC, Big Mac and Currency, compared to the base for Sydney of 1$)$. The results are shown in Table $6(n=23)$ and Table $7(n=46)$. Each is categorised into upper (25\%), middle (50\%) and lower (25\%) quartiles using the indices from Expatistan (listed earlier in Table 2) that depict a cost of living from expensive (San Francisco $=1.16$ ) to good value (Istanbul $=0.62)$.

\section{Insert Table 6 here ...}

\section{Insert Table 7 here ...}

Table 8 summarises the comparison of methods, and as previously discovered in Langston (2016), clearly shows that citiBLOC has the lowest CoV for both $n=23$ and $n=46$ datasets. In fact, the difference between the two datasets is negligible. However, only citiBLOC falls below the maximum target based on the mean CoV of the five conversion methods for each city. Ignoring the outlier for Big Mac in Hong Kong, currency conversion has the highest values for CoV, range and comparison to base. When subdivided into expensive (upper quartile), mid-range (middle quartile) and good value (lower quartile), the CoV for citiBLOC is even lower - averaging close to or under $20 \%$ (see Table 9).

Insert Table 8 here ...

Insert Table 9 here ... 


\section{Discussion}

Focusing further on the citiBLOC indices, it can be seen that each of upper, middle and lower quartile data compute a regression line (line of best fit) that is quite flat. There is considerable volatility and a low $r^{2}$ value in each case, which may have more to do with the accuracy of Expatistan's cost of living index used to rank the cities. Each quartile is presented in Figure 1 ( $n=23$ and $n=46)$.

\section{Insert Figure 1 here ...}

Figure 2 graphically illustrates index volatility of the equivalent cost $/ \mathrm{m}^{2}$ values for each of the 46 cities in Turner and Townsend (2018). They are listed in order of decreasing cost of living from left to right. The overall trend lines for cost $/ \mathrm{m}^{2}$ generally decline in keeping with the cost of living, and the reason citiBLOC has the lowest CoV is probably because this method is the best at smoothing out the data. This is because mean cost $/ \mathrm{m}^{2}$ (in local currency) divided by a balanced cost/basket of local commodities (also in local currency) produces a more stable ratio (i.e. basket $/ \mathrm{m}^{2}$ ). Cost effectively cancels out, as does currency conversion. Resultant variations are therefore reflecting other differences between locations, such as productivity levels, contractor margins, standards of construction, statutory requirements, local practices and concern for worker health and safety.

\section{Insert Figure 2 here ...}

One of the big differences between cities in this study is the cost of labour. Using the data in Table 4, the ratio of labour to material in the L+M PPP can be computed. This varies from 55:45 (Zurich) to 8:92 (Bogatá). The mean ratio across all cities is 27:73 $(n=23)$ and 30:70 $(n=46)$. High labour-cost and low labour-cost cities have been shaded differently in Figure 2 earlier. Not all low labour-cost cities have lower values for cost of living, with Hong Kong, Singapore, Doha and Dubai/Abu Dhabi being notable examples. However, all cities in the lower quartile ( $n=23$ and $n=46$ ) deploy cheap labour in construction (mean ratio is 15:85 in both cases).

Finally, it should be noted that any city can be selected as the base. Turner and Townsend (2013) used Sydney, as does this study, but later surveys changed the base to London. The choice of base has no effect on the conclusions reached herein. 


\section{Conclusion}

The conclusion from Langston (2016:74) stated that:

Construction project costs between countries cannot be compared reliably using currency exchange rates, as this fails to take account of the local cost of living. The citiBLOC PPP uses a standard basket of 10 construction items, comprising notional 50\% material, 40\% labour and 10\% plant, to calculate PPP values in each city. The average price of items in the standard basket for a particular city is then divided by the average price for a base city to calculate relative PPPs. When benchmarking international project cost performance, making relative cost comparisons between cities in different countries is necessary. PPP is the correct methodology to apply.

This paper demonstrates that citiBLOC PPPs have the lowest CoV of any of the five methods investigated, and using the Law of One Price as the test, certainly out-perform currency conversion in terms of lower volatility. Given that most practitioners still use USD currency conversion to draw conclusions about relative cost performance in different locations, it seems that many of their conclusions may be unreliable or erroneous. While presentation of construction project costs in terms of USD or other standard currency has its place, citiBLOCPPP is the preferred method whenever judgements about relative project cost performance are involved.

Exactly the same conclusion can now be drawn from the 2018 data presented in this chapter. This study has added further confidence in the earlier work, and the findings are most likely to be repeatable in future years.

\section{References}

Baffes, J. (1991), Some further evidence on the law of one price: the law of one price still holds, American Journal of Agricultural Economics, 73(4), 1264-1273.

Best, R. (2008), The development and testing of a purchasing power parity method for comparing construction costs internationally, PhD thesis, University of Technology, Sydney. 
Best, R. and Meikle, J. eds. (2015), Measuring construction: prices, output and productivity, Routledge.

Gustav, C. (1918), Abnormal deviations in international exchanges, The Economic Journal, 28(112), 413-415.

Krugman, P., Obstfeld, M. and Meiltz, M. (2010), International Economics ( $9^{\text {th }}$ Edition), Pearson Higher Ed, Boston.

Langston, C. (2014), Construction efficiency: a tale of two developed countries, Engineering, Construction and Architectural Management, 21(3), 320-355.

Langston, C. (2016), The reliability of currency and purchasing power parity conversion for international project cost benchmarking, Benchmarking: An International Journal, 23(1), 6177.

Langston, C. and Best, R. (2005), Using the Big Mac Index for comparing construction costs internationally, in proceedings of QUT Research Week, Brisbane, July.

Pakko, M.R. and Pollard, P.S. (2003), Burgernomics: a Big Mac ${ }^{\mathrm{TM}}$ guide to purchasing power parity, Federal Reserve Bank of St. Louis Review, 85(6), 9-28.

Rogoff, K. (1996), The purchasing power puzzle, Journal of Economic Literature, XXXIV(2), 647-668.

Turner and Townsend (2013), International construction cost survey 2013, available at: http://www.turnerandtownsend.com/en/insights/international-construction-cost-survey2013/ (accessed 5 December 2013).

Turner and Townsend (2018), International construction market survey 2018, available at: http://www.turnerandtownsend.com/en/insights/international-construction-marketsurvey-2018/ (accessed 2 June 2018).

UBS (2003) Prices and earnings: a comparison of purchasing power parity around the globe (2003 Edition), Union Bank of Switzerland, Zurich. 
Table 1: Representative construction items for citiBLOC (Langston, 2014; 2016)

\begin{tabular}{|c|c|c|c|c|c|}
\hline Item & \multicolumn{2}{|c|}{ Standard Description } & Unit & $\begin{array}{c}\text { Quantity } \\
\text { (weighting) }\end{array}$ & $\begin{array}{c}\text { Local Currency } \\
(\text { ex-tax })\end{array}$ \\
\hline \multicolumn{6}{|c|}{ Material (supply only including CBD delivery) } \\
\hline$A$ & $32 \mathrm{MPa}$ ready-mixed concrete & $\left(1 \mathrm{~m}^{3}=35.31 \mathrm{cu} . \mathrm{feet}\right)$ & $m^{3}$ & 45 & 11,144 \\
\hline B & Steel in $250 \times 25.7 \mathrm{~kg} / \mathrm{m}$ 'I' beam & (17.3 lb/foot) & $\mathrm{t}$ & 6.8 & 9,350 \\
\hline $\mathrm{C}$ & $10 \mathrm{~mm}$ clear tempered glass & $\left(1 \mathrm{~m}^{2}=10.76 \mathrm{sq} . \mathrm{feet}\right)$ & $\mathrm{m}^{2}$ & 44 & 10,472 \\
\hline $\mathrm{D}$ & $13 \mathrm{~mm}$ thick gypsum plasterboard & $(1 / 2 "$ thick) & $\mathrm{m}^{2}$ & 1,300 & 10,140 \\
\hline $\mathrm{E}$ & $100 \times 50 \mathrm{~mm}$ sawn softwood stud & (1 $\mathrm{m}=3.28 \mathrm{feet})$ & $\mathrm{m}$ & 2,750 & 9,873 \\
\hline \multicolumn{6}{|c|}{ Labour (charge-out rate including on-costs) } \\
\hline $\mathrm{F}$ & Electrician & & $\mathrm{hr}$ & 150 & 9,900 \\
\hline G & Carpenter & & $\mathrm{hr}$ & 185 & 10,915 \\
\hline $\mathrm{H}$ & Painter & & $\mathrm{hr}$ & 200 & 10,400 \\
\hline 1 & Unskilled labour & & $\mathrm{hr}$ & 275 & 10,863 \\
\hline \multicolumn{6}{|c|}{ Plant (third party hire rate including operator and fuel) } \\
\hline J & 50 t mobile crane & & day & 5 & 10,200 \\
\hline
\end{tabular}

average price per item (i.e. 1 citiBLOC):

10,326

SYDNEY, AUSTRALIA (2012)

Current Market Conditions: $\quad \square$ very competitive (low profit) $\quad \square$ normal $\quad \square$ overheated (high profit) 
Table 2: Surveyed locations (Turner and Townsend, 2018)

\begin{tabular}{|c|c|c|c|}
\hline City & Country & Currency & Expatistan^ \\
\hline Amsterdam* & The Netherlands & EUR & 0.89 \\
\hline Bangalore** & Republic of India & INR & 0.67 \\
\hline Beijing & People's Republic of China & CNY & 0.81 \\
\hline Belfast & United Kingdom & GBP & 0.75 \\
\hline Birmingham & United Kingdom & GBP & 0.79 \\
\hline Bogotá & Republic of Columbia & COP & 0.65 \\
\hline Brisbane & Commonwealth of Australia & AUD & 0.85 \\
\hline Buenos Aires & Argentine Republic (Argentina) & ARS & 0.63 \\
\hline Dar es Salaam & United Republic of Tanzania & TZS & 0.67 \\
\hline Doha* & State of Qatar & QAR & 0.92 \\
\hline Dubai* / Abu Dhabi & United Arab Emirates & AED & 0.88 \\
\hline Dublin* & Republic of Ireland & EUR & 1.00 \\
\hline Edinburgh & United Kingdom & GBP & 0.81 \\
\hline Ho Chi Minh City* & Socialist Republic of Vietnam & VND & 0.64 \\
\hline Hong Kong* & Hong Kong SAR, People's Republic of China & HKD & 1.04 \\
\hline Houston & United States of America & USD & 0.78 \\
\hline Istanbul & Republic of Turkey & TRY & 0.62 \\
\hline Jakarta & Republic of Indonesia & IDR & 0.63 \\
\hline Johannesburg* & Republic of South Africa & ZAR & 0.70 \\
\hline Kampala* & Republic of Uganda & UGX & 0.65 \\
\hline Kigali & Republic of Rwanda & RWF & 0.63 \\
\hline Kuala Lumpur* & Malaysia & MYR & 0.64 \\
\hline London* & United Kingdom & GBP & 1.08 \\
\hline Madrid & Kingdom of Spain & EUR & 0.74 \\
\hline Melbourne & Commonwealth of Australia & AUD & 0.88 \\
\hline Moscow* & Russian Federation & RUB & 0.67 \\
\hline Munich** & Federal Republic of Germany & EUR & 0.83 \\
\hline Muscat* & Sultanate of Oman & OMR & 0.70 \\
\hline Nairobi & Republic of Kenya & $\mathrm{KSH}$ & 0.67 \\
\hline New York City & United States of America & USD & 1.10 \\
\hline Paris & French Republic (France) & EUR & 0.95 \\
\hline Perth & Commonwealth of Australia & AUD & 0.83 \\
\hline San Francisco** & United States of America & USD & 1.16 \\
\hline Santiago & Republic of Chile & CLP & 0.69 \\
\hline Säo Paulo* & Federative Republic of Brazil & BRL & 0.68 \\
\hline Seattle & United States of America & USD & 0.94 \\
\hline Seoul* & Republic of Korea (South Korea) & KRW & 0.78 \\
\hline Shanghai* & People's Republic of China & CNY & 0.74 \\
\hline Singapore* & Republic of Singapore & SGD & 0.94 \\
\hline Southampton & United Kingdom & GBP & 0.76 \\
\hline Sydney* & Commonwealth of Australia & AUD & 1.00 (base) \\
\hline Tokyo* & Japan & JPY & 0.90 \\
\hline Toronto* & Canada & CAD & 0.85 \\
\hline Warsaw* & Republic of Poland & PLN & 0.64 \\
\hline York & United KIngdom & GBP & 0.78 \\
\hline Zurich & Swiss Confederation (Switzerland) & $\mathrm{CHF}$ & 1.14 \\
\hline
\end{tabular}

* cities common to Turner and Townsend (2013)

** ditto, but similar city (e.g. Los Angeles replaced with San Francisco)

$\wedge$ Expatistan is a broad-based 'cost of living' index (accessed 2 June 2018) 
Table 3: Coefficients of variation (average cost $/ \mathrm{m}^{2}$ )

\begin{tabular}{|c|c|c|c|c|}
\hline \multirow[b]{2}{*}{ Building type (Turner and Townsend, 2013; 2018) } & \multicolumn{2}{|c|}{ Common $(n=23)$} & \multicolumn{2}{|c|}{ Extended $(n=46)$} \\
\hline & $\%(U S D)$ & $\%(P P P)$ & $\%(U S D)$ & $\%(P P P)$ \\
\hline \multicolumn{5}{|l|}{ Residential } \\
\hline Individual detached/terrace house medium standard & 67 & 46 & 61 & 43 \\
\hline Individual detached house prestige & 77 & 53 & 67 & 47 \\
\hline Townhouses medium standard & 66 & 44 & 58 & 42 \\
\hline Apartments low rise medium density & 59 & 34 & 55 & 36 \\
\hline Apartments high rise & 57 & 31 & 54 & 34 \\
\hline Aged care/affordable units & 76 & 54 & 63 & 46 \\
\hline \multicolumn{5}{|l|}{ Commercial } \\
\hline Offices - business park & 52 & 24 & 52 & 30 \\
\hline CBD offices - up to 20 floors medium (A-Grade) & 57 & 22 & 56 & 25 \\
\hline CBD offices - high rise prestige & 56 & 24 & 54 & 24 \\
\hline \multicolumn{5}{|l|}{ Industrial } \\
\hline Warehouse/factory units - basic & 59 & 48 & 53 & 45 \\
\hline Large warehouse distribution centre & 52 & 36 & 47 & 37 \\
\hline High tech factory/laboratory & 57 & 32 & 53 & 36 \\
\hline \multicolumn{5}{|l|}{ Retail } \\
\hline Large shopping centre including mall & 56 & 29 & 51 & 29 \\
\hline Neighbourhood incl. supermarket & 57 & 33 & 54 & 35 \\
\hline Prestige car showroom & 54 & 39 & 52 & 37 \\
\hline \multicolumn{5}{|l|}{ Hotels } \\
\hline 3 star travellers & 45 & 26 & 42 & 27 \\
\hline 5 star luxury & 40 & 25 & 40 & 30 \\
\hline Resort style & 45 & 42 & 40 & 39 \\
\hline \multicolumn{5}{|l|}{ Hospitals } \\
\hline Day centre (including basic surgeries) & 57 & 41 & 50 & 34 \\
\hline Regional hospital & 63 & 40 & 59 & 34 \\
\hline General hospital (e.g. city teaching hospital) & 65 & 44 & 55 & 36 \\
\hline \multicolumn{5}{|l|}{ Schools } \\
\hline Primary and secondary & 55 & 35 & 52 & 35 \\
\hline University & 54 & 26 & 52 & 31 \\
\hline \multicolumn{5}{|l|}{ Carparks } \\
\hline Multi storey above ground & 53 & 34 & 48 & 33 \\
\hline Multi storey below ground & 73 & 47 & 63 & 42 \\
\hline \multicolumn{5}{|l|}{ Airports } \\
\hline Domestic terminal, full service & 49 & 43 & 42 & 33 \\
\hline Low cost carrier, basic service & 48 & 42 & 40 & 32 \\
\hline Proportion lowest CoV (\%) & 0.00 & 100.00 & 0.00 & 100.00 \\
\hline
\end{tabular}

bold figures indicate lowest CoV 
Table 4: Coefficients of variation (labour, material and plant)

\begin{tabular}{|c|c|c|c|c|}
\hline \multirow[b]{2}{*}{ Item (Turner and Townsend, 2013; 2018) } & \multicolumn{2}{|c|}{ Common $(n=23)$} & \multicolumn{2}{|c|}{ Extended $(n=46)$} \\
\hline & $\%$ (USD) & $\%(P P P)$ & $\%$ (USD) & $\%(P P P)$ \\
\hline \multicolumn{5}{|l|}{ Labour (cost/hour) } \\
\hline Group 1 tradesman (e.g. plumber/electrician) \# & 98 & 69 & 91 & 62 \\
\hline Group 2 tradesman (e.g. carpenter/bricklayer) \# & 96 & 66 & 89 & 59 \\
\hline Group 3 tradesman (e.g. carpet layer/tiler/plasterer) \# & 92 & 64 & 89 & 59 \\
\hline General labourer \# & 97 & 70 & 97 & 65 \\
\hline Site foreman & 89 & 57 & 87 & 54 \\
\hline Proportion lowest CoV (\%) & 0.00 & 100.00 & 0.00 & 100.00 \\
\hline \multicolumn{5}{|l|}{ Material (cost/unit) } \\
\hline Concrete $30 \mathrm{MPa}\left(\mathrm{m}^{3}\right) \#$ & 36 & 46 & 35 & 43 \\
\hline Reinforcement bar 16mm (tonne) & 26 & 34 & 23 & 34 \\
\hline Concrete block 400 x 200mm (thousands) & 81 & 63 & 78 & 57 \\
\hline Standard brick (thousands) & 62 & 65 & 57 & 59 \\
\hline Structural steel beams (tonne) \# & 35 & 35 & 36 & 34 \\
\hline Glass pane $10 \mathrm{~mm}$ tempered $\left(\mathrm{m}^{2}\right) \#$ & 51 & 47 & 47 & 41 \\
\hline Softwood timber for framing $100 \times 50 \mathrm{~mm}(\mathrm{~m}) \#$ & 44 & 42 & 38 & 46 \\
\hline $13 \mathrm{~mm}$ plasterboard $\left(\mathrm{m}^{2}\right) \#$ & 47 & 36 & 44 & 41 \\
\hline Emulsion paint (litre) & 54 & 53 & 56 & 80 \\
\hline Copper pipe $15 \mathrm{~mm}(\mathrm{~m})$ & 49 & 51 & 50 & 55 \\
\hline Copper cable $(3 C+E) 2.5 \mathrm{~mm}$ PVC (m) & 87 & 83 & 77 & 77 \\
\hline Proportion lowest CoV (\%) & 36.36 & 63.64 & 63.64 & 36.36 \\
\hline \multicolumn{5}{|l|}{ Plant (cost/day) } \\
\hline Hire 50 tonne mobile crane + operator \# & 51 & 24 & 54 & 22 \\
\hline Proportion lowest CoV (\%) & 0.00 & 100.00 & 0.00 & 100.00 \\
\hline
\end{tabular}

\# items are used to construct citiBLOC PPP

bold figures indicate lowest CoV 
Table 5: Coefficients of variation (composite work items)

\begin{tabular}{|c|c|c|c|c|}
\hline \multirow[b]{2}{*}{ Item (Turner and Townsend, 2013; 2018) } & \multicolumn{2}{|c|}{ Common $(n=23)$} & \multicolumn{2}{|c|}{ Extended $(n=46)$} \\
\hline & $\%$ (USD) & $\%$ (PPP) & $\%$ (USD) & $\%(\mathrm{PPP})$ \\
\hline Excavate basement $\left(\mathrm{m}^{3}\right)$ & 86 & 76 & 76 & 67 \\
\hline Excavate footings (m) & 68 & 60 & 68 & 56 \\
\hline Concrete in slab $\left(\mathrm{m}^{3}\right)$ & 36 & 33 & 40 & 28 \\
\hline Reinforcement in beams (tonne) & 28 & 34 & 28 & 31 \\
\hline Formwork to soffit of slab $\left(\mathrm{m}^{2}\right)$ & 77 & 44 & 71 & 45 \\
\hline Blockwork in wall $\left(\mathrm{m}^{2}\right)$ & 68 & 35 & 76 & 37 \\
\hline Structural steel beams (tonne) & 40 & 31 & 44 & 31 \\
\hline Pre-cast concrete wall $\left(\mathrm{m}^{2}\right)$ & 42 & 60 & 61 & 57 \\
\hline Curtain wall glazing including support system $\left(\mathrm{m}^{2}\right)$ & 52 & 32 & 59 & 35 \\
\hline Plasterboard $13 \mathrm{~mm}$ thick to stud wall $\left(\mathrm{m}^{2}\right)$ & 51 & 45 & 51 & 43 \\
\hline Single solid core door including frame/hardware (no.) & 53 & 60 & 55 & 54 \\
\hline Painting to walls, primer + two coats $\left(\mathrm{m}^{2}\right)$ & 60 & 47 & 54 & 43 \\
\hline Ceramic tiling $\left(\mathrm{m}^{2}\right)$ & 48 & 25 & 57 & 28 \\
\hline Vinyl flooring to wet areas $\left(\mathrm{m}^{2}\right)$ & 26 & 44 & 39 & 51 \\
\hline Carpet medium tufted $\left(\mathrm{m}^{2}\right)$ & 35 & 56 & 33 & 57 \\
\hline Lighting installation $\left(\mathrm{m}^{2}\right)$ & 48 & 41 & 53 & 48 \\
\hline Copper pipe $15 \mathrm{~mm}$ to wall (m) & 62 & 38 & 54 & 30 \\
\hline Fire sprinklers ( $\mathrm{m}^{2}$ serviced area) & 61 & 38 & 54 & 39 \\
\hline Air conditioning including main plant ( $\mathrm{m}^{2}$ serviced area) & 50 & 30 & 53 & 31 \\
\hline Proportion lowest CoV (\%) & 26.32 & 73.68 & 15.79 & 84.21 \\
\hline
\end{tabular}

bold figures indicate lowest CoV 
Table 6: Average cost $/ \mathrm{m}^{2}$ (various conversion methods, $n=23$ )

\begin{tabular}{|c|c|c|c|c|c|c|}
\hline City & Local Currency & citiBLOC & $L+M$ & Composite & Big Mac & Currency \\
\hline \multicolumn{7}{|c|}{ Expensive (upper quartile) } \\
\hline San Francisco & 3,488 & 3,303 & 3,473 & 3,214 & 3,897 & 4,569 \\
\hline London & 2,518 & 4,546 & 4,356 & 3,996 & 4,657 & 4,458 \\
\hline Hong Kong & 29,521 & 5,317 & 4,720 & 4,267 & $\wedge 8,496$ & 4,958 \\
\hline Dublin & 2,513 & 4,129 & 3,172 & 4,030 & 3,754 & 3,919 \\
\hline Sydney (base) & 3,311 & 3,311 & 3,311 & 3,311 & 3,311 & 3,311 \\
\hline Singapore & 2,982 & 4,174 & 3,465 & 3,470 & 3,034 & 2,960 \\
\hline \multicolumn{7}{|c|}{ Mid-range (middle quartile) } \\
\hline Doha & 7,919 & 5,289 & 3,881 & 3,424 & 3,894 & 2,850 \\
\hline Tokyo & 313,370 & 4,103 & 4,010 & 6,007 & 4,865 & 3,698 \\
\hline Amsterdam & 2,114 & 4,308 & 3,969 & 3,063 & 3,158 & 3,298 \\
\hline Dubai/Abu Dhabi & 6,877 & 5,408 & 3,687 & 3,354 & 2,898 & 2,455 \\
\hline Toronto & 3,131 & 3,318 & 3,034 & 3,846 & 2,820 & 3,205 \\
\hline Munich & 2,019 & 3,523 & 3,089 & 3,321 & 3,016 & 3,149 \\
\hline Seoul & $1,965,743$ & 4,503 & 4,206 & 4,208 & 2,636 & 2,362 \\
\hline Shanghai & 5,596 & 3,687 & 2,153 & 2,253 & 1,619 & 1,145 \\
\hline Johannesburg & 13,380 & 2,454 & 1,669 & 2,994 & 2,631 & 1,452 \\
\hline Muscat & 600 & 5,285 & 3,131 & 3,607 & 3,145 & 2,014 \\
\hline Säo Paulo & 4,767 & 3,896 & 3,080 & 3,192 & 1,705 & 1,934 \\
\hline \multicolumn{7}{|c|}{ Good value (lower quartile) } \\
\hline Bangalore & 46,225 & 4,200 & 2,188 & 2,142 & 1,515 & 939 \\
\hline Moscow & 72,802 & 3,703 & 3,316 & 2,337 & 3,304 & 1,633 \\
\hline Kampala & $4,241,835$ & 2,943 & 1,299 & 2,967 & 2,319 & 1,525 \\
\hline Kuala Lumpur & 4,366 & 3,075 & 1,890 & 2,913 & 2,862 & 1,451 \\
\hline Warsaw & 3,960 & 3,203 & 2,675 & 2,764 & 2,313 & 1,526 \\
\hline \multirow[t]{3}{*}{ Ho Chi Minh City } & $19,029,238$ & 2,437 & 1,620 & 2,041 & 1,727 & 1,093 \\
\hline & $\operatorname{CoV}(\%)$ & 22.38 & 30.09 & 25.71 & 45.50 & 46.00 \\
\hline & Range & 2,971 & 3,421 & 3,966 & 6,981 & 4,019 \\
\hline
\end{tabular}

$\wedge$ Big Mac price in HK is a clear outlier bold figures indicate highest and lowest cost $/ \mathrm{m}^{2}$, CoV or range 
Table 7: Average cost $/ \mathrm{m}^{2}$ (various conversion methods, $\mathrm{n}=46$ )

\begin{tabular}{|c|c|c|c|c|c|c|}
\hline City & Local Currency & citiBLOC & $\mathrm{L}+\mathrm{M}$ & Composite & Big Mac & Currency \\
\hline \multicolumn{7}{|c|}{ Expensive (upper quartile) } \\
\hline San Francisco & 3,488 & 3,303 & 3,473 & 3,214 & 3,897 & 4,569 \\
\hline Zurich & 3,434 & 2,988 & 2,732 & 3,328 & 3,117 & 4,591 \\
\hline New York City & 3,644 & 3,080 & 3,289 & 2,823 & 4,072 & 4,773 \\
\hline London & 2,518 & 4,546 & 4,356 & 3,996 & 4,657 & 4,458 \\
\hline Hong Kong & 29,521 & 5,317 & 4,720 & 4,267 & $\wedge 8,496$ & 4,958 \\
\hline Dublin & 2,513 & 4,129 & 3,172 & 4,030 & 3,754 & 3,919 \\
\hline Sydney (base) & 3,311 & 3,311 & 3,311 & 3,311 & 3,311 & 3,311 \\
\hline Paris & 2,095 & 4,096 & 3,750 & 3,262 & 3,267 & 3,267 \\
\hline Singapore & 2,982 & 4,174 & 3,465 & 3,470 & 3,034 & 2,960 \\
\hline Seattle & 2,937 & 2,972 & 3,278 & 2,816 & 3,282 & 3,848 \\
\hline Doha & 7,919 & 5,289 & 3,881 & 3,424 & 3,894 & 2,850 \\
\hline Tokyo & 313,370 & 4,103 & 4,010 & 6,007 & 4,865 & 3,698 \\
\hline \multicolumn{7}{|c|}{ Mid-range (middle quartile) } \\
\hline Amsterdam & 2,114 & 4,308 & 3,969 & 3,063 & 3,158 & 3,298 \\
\hline Dubai/Abu Dhabi & 6,877 & 5,408 & 3,687 & 3,354 & 2,898 & 2,455 \\
\hline Melbourne & 2,941 & 2,919 & 2,883 & 3,086 & 2,941 & 2,941 \\
\hline Toronto & 3,131 & 3,318 & 3,034 & 3,846 & 2,820 & 3,205 \\
\hline Brisbane & 2,935 & 3,268 & 3,103 & 3,074 & 2,935 & 2,935 \\
\hline Munich & 2,019 & 3,523 & 3,089 & 3,321 & 3,016 & 3,149 \\
\hline Perth & 2,733 & 3,239 & 3,255 & 3,588 & 2,733 & 2,733 \\
\hline Edinburgh & 1,830 & 4,196 & 3,878 & 4,090 & 3,384 & 3,239 \\
\hline Beijing & 5,858 & 3,822 & 2,273 & 2,384 & 1,694 & 1,199 \\
\hline Birmingham & 1,853 & 4,180 & 4,070 & 4,108 & 3,428 & 3,281 \\
\hline York & 1,831 & 4,102 & 4,004 & 4,085 & 3,386 & 3,241 \\
\hline Houston & 2,367 & 2,925 & 2,865 & 2,858 & 2,645 & 3,101 \\
\hline Seoul & $1,965,743$ & 4,503 & 4,206 & 4,208 & 2,636 & 2,362 \\
\hline Southampton & 2,047 & 4,063 & 3,960 & 3,830 & 3,785 & 3,623 \\
\hline Belfast & 1,629 & 4,569 & 4,215 & 4,475 & 3,013 & 2,884 \\
\hline Madrid & 1,728 & 3,691 & 3,273 & 3,650 & 2,581 & 2,695 \\
\hline Shanghai & 5,596 & 3,687 & 2,153 & 2,253 & 1,619 & 1,145 \\
\hline Johannesburg & 13,380 & 2,454 & 1,669 & 2,994 & 2,631 & 1,452 \\
\hline Muscat & 600 & 5,285 & 3,131 & 3,607 & 3,145 & 2,014 \\
\hline Santiago & $1,7017,832$ & 4,106 & 2,847 & 3,038 & 2,310 & 2,195 \\
\hline Säo Paulo & 4,767 & 3,896 & 3,080 & 3,192 & 1,705 & 1,934 \\
\hline Bangalore & 46,225 & 4,200 & 2,188 & 2,142 & 1,515 & 939 \\
\hline \multicolumn{7}{|c|}{ Good value (lower quartile) } \\
\hline Moscow & 72,802 & 3,703 & 3,316 & 2,337 & 3,304 & 1,633 \\
\hline Dar es Salaam & $2,177,070$ & 2,378 & 1,602 & 2,904 & 1,468 & 1,270 \\
\hline Narobi & 90,426 & 1,939 & 1,247 & 2,899 & 1,875 & 1,150 \\
\hline Kampala & $4,241,835$ & 2,943 & 1,299 & 2,967 & 2,319 & 1,525 \\
\hline Bogatá & $3,674,074$ & 2,555 & 1,769 & 2,362 & 1,989 & 1,603 \\
\hline Kuala Lumpur & 4,366 & 3,075 & 1,890 & 2,913 & 2,862 & 1,451 \\
\hline Warsaw & 3,960 & 3,203 & 2,675 & 2,764 & 2,313 & 1,526 \\
\hline Ho Chi Minh City & $19,029,238$ & 2,437 & 1,620 & 2,041 & 1,727 & 1,093 \\
\hline Jakarta & $12,620,370$ & 3,722 & 2,734 & 3,822 & 2,083 & 1,225 \\
\hline Buenos Aires & 24,626 & 4,039 & 2,051 & 4,871 & 1,937 & 1,702 \\
\hline Kigali & $1,067,571$ & 2,779 & 1,194 & 2,122 & 2,668 & 1,620 \\
\hline \multirow[t]{3}{*}{ Istanbul } & 3,264 & 3,069 & 2,466 & 2,955 & 1,791 & 1,094 \\
\hline & $\operatorname{CoV}(\%)$ & 22.39 & 30.34 & 23.28 & 39.27 & 43.51 \\
\hline & Range & 3,469 & 3,526 & 3,966 & 7,028 & 4,019 \\
\hline
\end{tabular}

$\wedge$ Big Mac price in HK is a clear outlier bold figures indicate highest and lowest cost $/ \mathrm{m}^{2}$, CoV or range 
Table 8: Comparison summary (various conversion methods)

\begin{tabular}{|c|c|c|c|c|}
\hline Method & & CoV & Range & $\begin{array}{c}\text { Compared } \\
\text { to Base }\end{array}$ \\
\hline \multicolumn{5}{|l|}{ Common $(n=23)$} \\
\hline$L+M$ & & $30.09 \%$ & 3,421 & $3.32 \%$ \\
\hline Composite & & $25.71 \%$ & 3,966 & $19.78 \%$ \\
\hline citiBLOC (preferred) & & $22.38 \%$ & 2,971 & $-10.27 \%$ \\
\hline Big Mac (not recommended) & & $45.50 \%$ & 6,981 & $110.84 \%$ \\
\hline \multirow[t]{2}{*}{ Currency (not recommended) } & & $46.00 \%$ & 4,019 & $21.38 \%$ \\
\hline & Maximum target & $\wedge 24.23 \%$ & 0 & $0.00 \%$ \\
\hline \multicolumn{5}{|l|}{ Extended $(n=46)$} \\
\hline $\mathrm{L}+\mathrm{M}$ & & $30.34 \%$ & 3,526 & $6.49 \%$ \\
\hline Composite & & $23.28 \%$ & 3,966 & $19.78 \%$ \\
\hline citiBLOC (preferred) & & $22.39 \%$ & 3,469 & $4.77 \%$ \\
\hline Big Mac (not recommended) & & $39.27 \%$ & 7,028 & $112.26 \%$ \\
\hline \multirow[t]{2}{*}{ Currency (not recommended) } & & $43.51 \%$ & 4,019 & $21.38 \%$ \\
\hline & Maximum target & $\wedge 22.78 \%$ & 0 & $0.00 \%$ \\
\hline
\end{tabular}

shaded figures indicate lowest values and bold figures indicate highest values

$\wedge$ mean of CoV across the five conversion methods for each city 
Table 9: citiBLOC summary (by quartile)

\begin{tabular}{|c|c|c|c|c|}
\hline Quartile & & $\mathrm{CoV}$ & Range & $\begin{array}{c}\text { Compared } \\
\text { to Base }\end{array}$ \\
\hline \multicolumn{5}{|l|}{ Common dataset $(n=23)$} \\
\hline Expensive (upper quartile) & & $18.56 \%$ & 2,014 & $-39.17 \%$ \\
\hline Mid-range (middle quartile) & & $22.23 \%$ & 2,954 & $-10.79 \%$ \\
\hline \multirow[t]{2}{*}{ Good value (lower quartile) } & & $18.88 \%$ & 1,763 & $-46.76 \%$ \\
\hline & Mean & $19.89 \%$ & 2,244 & $-32.24 \%$ \\
\hline \multicolumn{5}{|l|}{ Extended dataset $(n=46)$} \\
\hline Expensive (upper quartile) & & $21.10 \%$ & 2,345 & $-29.18 \%$ \\
\hline Mid-range (middle quartile) & & $18.46 \%$ & 2,954 & $-10.79 \%$ \\
\hline \multirow[t]{2}{*}{ Good value (lower quartile) } & & $20.75 \%$ & 2,100 & $-36.58 \%$ \\
\hline & Mean & $20.10 \%$ & 2,466 & $-25.51 \%$ \\
\hline
\end{tabular}



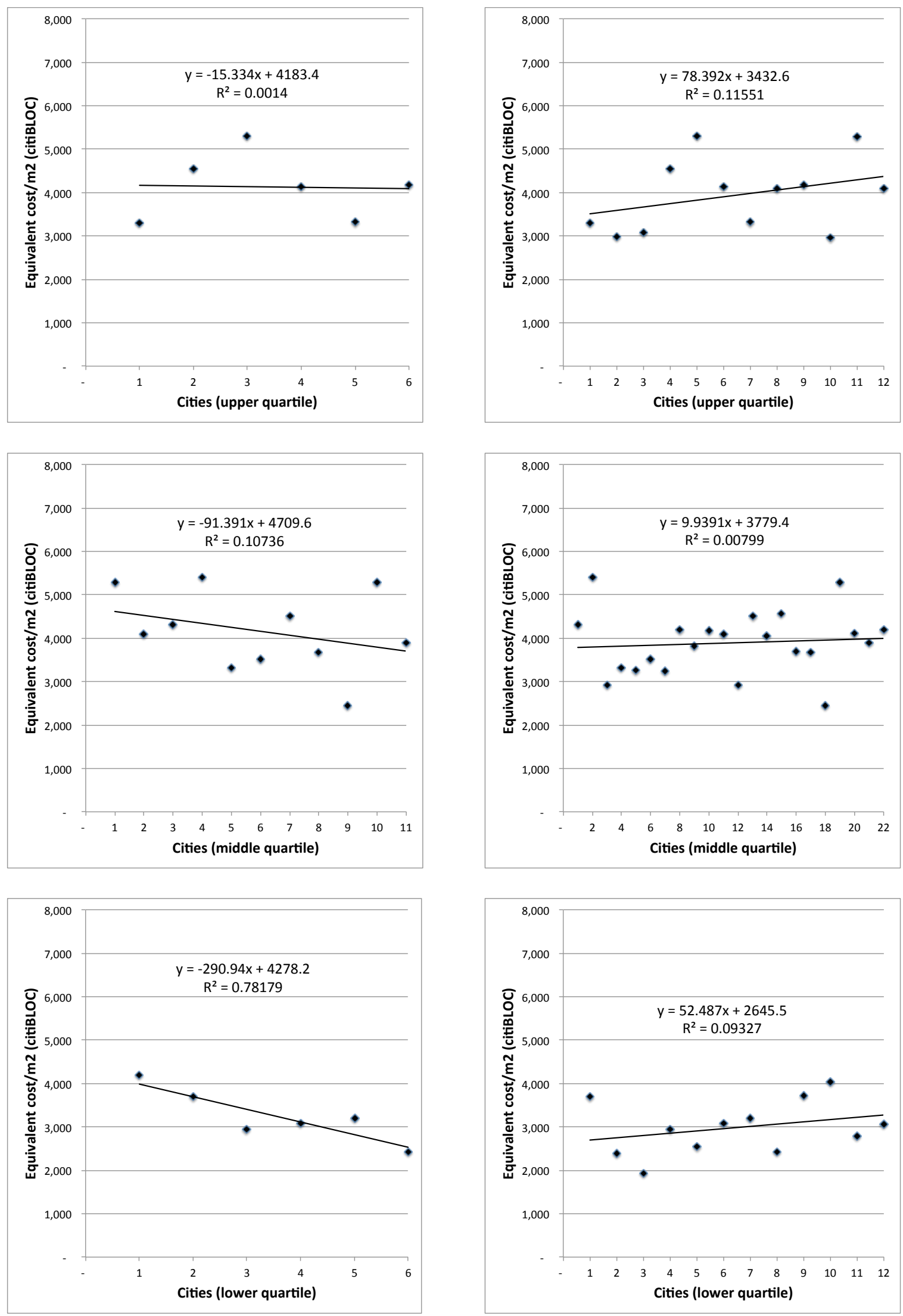

Figure 1: Regression analysis of equivalent cost $/ \mathrm{m}^{2}$ (by quartile) 


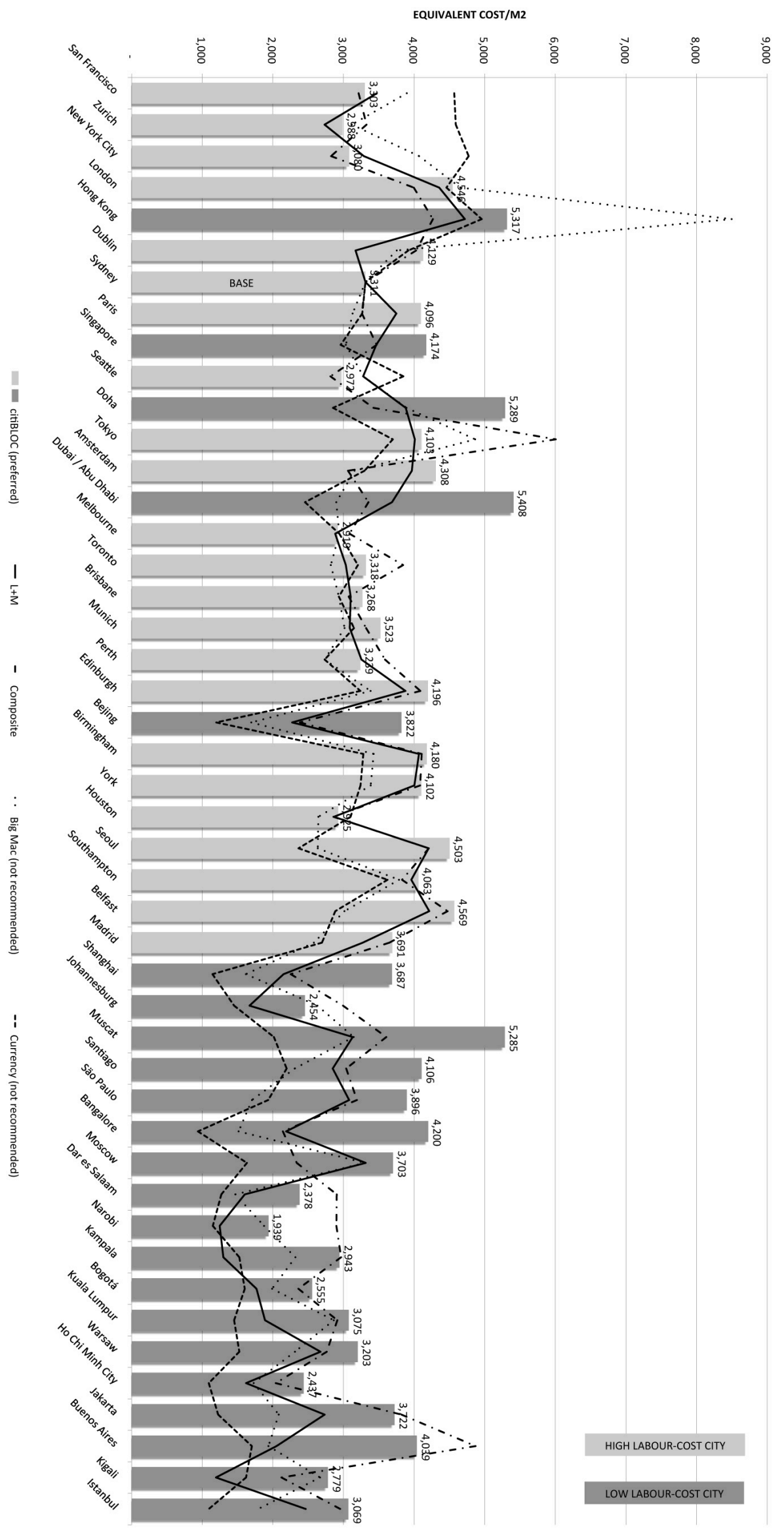

Figure 2: International cost benchmarking (various conversion methods, $n=46$ ) 